Recommendations for the development of a state internal audit system in conditions of using digital technologies have been elaborated. It was established that the procedures of conducting state internal audits change under influence of digitization. Conformity of the stages of audit digitization and the applied digital technologies was established. Foreign experience in the digitization of the state internal audit was analyzed. It was also established that the active application of artificial intelligence technologies may be one of the probable scenarios of the development of the state internal audit system in foreign countries in the near future. Types of digital technologies were systematized depending on the field of state internal audit. It was found that the maximum effect from the use of digital technologies in the field of audit will take place in the case of their synergistic combination. Coordinated interaction between constituent elements of the state internal audit has been established. This has made it possible to present the process of development of the state internal audit system in conditions of digitization and determine its main objective: ensure greater transparency and efficiency of accounting for tangible assets by means of new digital technologies. Taking into account the above, a mechanism of development of the system of state internal audit in conditions of use of digital technologies was offered. It is based on corresponding directions and measures. It was established that to assess the efficiency of development of the state internal audit system in conditions of application of digital technologies, it is advisable to use the indicators reflecting overall results of measures taken in state financial control. The application of the proposed mechanism zill make it possible to establish the effect of digital technologies on the development of the state internal audit

Keywords: state internal audit, digital technologies, digitization, financial audit, audit development
UDC 657.6:347.73

DOI: $10.15587 / 1729-4061.2022 .252424$

\section{ELABORATION OF RECOMMENDATIONS ON THE DEVELOPMENT OF THE STATE INTERNAL AUDIT SYSTEM WHEN APPLYING THE DIGITAL TECHNOLOGIES}

\author{
Volodymyr Korol \\ Corresponding author \\ Postgraduate Student* \\ E-mail: korolvladnik@yahoo.com \\ O Iga Dmytryk
}

Doctor of Law, Professor, Head of Department

Department of General Problems of Formation and Implementation of Innovation Policy Scientific and Research Institute of Providing Legal Framework for the Innovative Development National Academy of Legal Sciences of Ukraine

Pushkinskaya srt., 70, Kharkiv, Ukraine, 61024

Oleksandr Karpenko

Doctor of Science in Public Administration, Associate Professor, Head of Department Department of National Economy and Public Administration Kyiv National Economic University named after Vadym Hetman Peremohy ave., 54/1, Kyiv, Ukraine, 03057

Valeriia Riadinska

Doctor of Law, Professor, Head of Laboratory Research Laboratory of Problems of Legal and Organizational Support of the Ministry Activities State Research Institute of the Ministry of Internal Affairs of Ukraine

Y. Gutsalo lane, 4a, Kyiv, Ukraine, 01011

Oleks andr Basiuk Postgraduate Student

Department of Economic Policy and Management Educational and Scientific Institute «Institute of Public Administration» V. N. Karazin Kharkiv National University Svobody sq., 4, Kharkiv, Ukraine, 61022

D m y tro Kobylnik Doctor of Law, Associate Professor** Volodymyr Moroz Associate Professor*

OIha Safronova Associate Professor*

Eugene Alisov

Doctor of Law, Professor, Director of Institute** Investigation and Criminalistics Institute

Tetyana Mishchenko $\mathrm{PhD}$, Associate Professor Department of Audit, Public Financial Control and Analysis State Tax University

Universytetska str., 31, Irpin, Ukraine, 08205

*Department of Regional Policy Educational and Scientific Institute of Public Administration and Civil Service Taras Shevchenko National University of Kyiv Volodymyrska str., 60, Kyiv, Ukraine, 01033

**Department of Financial Law

Yaroslav Mudryi National Law University Pushkinskaya str., 77, Kharkiv, Ukraine, 61024

Received date 12.01.2022 How to Cite: Korol, V., Dmytryk, O., Karpenko, O., Riadinska, V., Basiuk, O., Kobylnik, D., Moroz, V., Safronova, O., Alisov, E., Mishchenko, T. Accepted date 10.02.2022 (2022). Elaboration of recommendations on the development of the state internal audit system when applying the digital technologies Eastern-European Journal of Enterprise Technologies, 1 (13 (115)), 39-48. doi: https://doi.org/10.15587/1729-4061.2022.252424

\section{Introduction}

Under the conditions of informatization and digitization, digital technologies have become an integral part of the socio-economic development of many countries covering all spheres of public life. Growing volumes of mobile connections, cloud computing, the rapid development of big data, and artificial intelligence are the main drivers 
of digitization acceleration. Besides, social networks play a significant role in this process performing the function of expanding public access to digital data. In such conditions, digital data are the main strategic resource optimizing opportunities to increase transparency and efficiency as well as speed up the decision-making process. Practices in planning and implementing digitization strategies around the world can vary widely, with many challenges in terms of data disclosure, sharing, integration, analysis, application, and security. In conditions of global digitization, there is an active phase of the digital transformation of the state. In this regard, the strategic goal consists of a $100 \%$ digitizing of public services in three years. In order to ensure success on the path to digitization, a new position has been introduced in local and territorial authorities: a deputy director for digital transformation [1].

Also, a project titled The Strategy of Digital Development, Transformation, and Digitization of the Public Financial Management System was approved at the governmental level at the end of 2021 for the period up to 2025 . At the same time, the project of digital transformation of the state financial control, e-Auditor, elaborated by the State Audit Office was presented [2]. It is believed that these steps will form the basis for improving the effectiveness of public financial control, ensure transparency, accountability, and high activity quality of government agencies. While fully apprehending the benefits of the digital economy and its new opportunities to use digital technologies, it is important to note the challenges that may arise along the way. First of all, this is because of rather high costs that require the creation of new systems and methods of data processing, not only in terms of work mechanization but also in terms of developing digital services themselves. In this case, it is necessary to clearly define requirements for those digital technologies that can actually be used in the state internal audit system. After that, it seems appropriate to purposefully implement and ensure organic interaction. In this regard, it seems appropriate to identify the impact of digital technologies on the development of the state internal audit system and develop lines of its improvement.

\section{Literature review and problem statement}

The spread of digitization processes to public administration has dramatically changed vectors of audit development, in particular, the internal audit system.

Study [3] is aimed at identifying the relationship between the introduction of digital technologies and activities of the public sector. In other words, e-governing entails digitization of the public sector through restructuring of activities, reorganization of public information and knowledge, and reorientation of relations between officials and citizens. At the same time, the study criticizes the digitization of the public sector and emphasizes an increased degree of responsibility of officials which is a limiting factor for such an approach. To solve this problem, the authors of [4] determine the leading role of managers in the functioning of internal audit. It should be noted that this article can be considered as an important contribution to the study of internal audit in terms of the effectiveness of the financial reporting process in a global context. It is focused on ensuring data integrity, review- ing risks and opportunities, assessing the adequacy of risk management and control, and providing assurances. However, issues of determining determinants of implementation of audit tools and methods using digital technologies among internal audit subdivisions remain unresolved. This approach is present in study [5] which complements previous studies applying a procedure of modeling hierarchical components to the extended structure of the digital environment and its implementation in internal audit. It emphasizes that governments and organizations should invest more in training seminars on big data analytics, hire more data processing specialists and/or engineers and equip internal audit units with digital infrastructure. The study results provide valuable information to senior management, audit managers, policymakers, and regulators on the ways to the improvement of implementation and application of digital technologies in the audit system.

It is worth pointing out studies [6,7] as more generalized studies concerning functions of internal audit in conditions of activization of digital environment In particular, the authors of study [6] note that the digital business environment affects the internal audit function in three aspects. First, it affects its scope and, in this connection, it is expected that flexibility of internal audit planning and the necessary digital knowledge will grow and the risks of digital technology, especially threats to cybersecurity, will become more important. Secondly, the demand for consulting activities of internal auditors is increasing and thirdly, digitization is changing the practice of internal auditors in their daily activities. Thus, new technologies, such as data analysis tools, are gradually being introduced into internal audit departments, and digital skills are an important asset. A similar approach is contained in [7] which emphasizes that digitization brings both new opportunities and threats to the business environment. This course of events requires that internal auditors acquire digital skills and enhance consulting capabilities so that this feature can help companies effectively manage the emerging risks. It is the factors contributing to the introduction of analytics of internal audit that are studied in [8]. At the same time, authors limit themselves to the study of the most critical factors including specific knowledge in the field of digitization, critical thinking skills, and business knowledge of the audit manager. In this regard, it is worth noting study [9] in which authors are focusing on the audit of financial accountability emphasizing that it is a complex and highly specialized process. Digitization and growing automation of transaction processing are creating new challenges for auditors. New methods of data analysis provide an opportunity to improve audit of financial accountability and overcome the limitations of conventional audit procedures. Implementation of the process analysis increases the reliability of auditor's reports and improves the reliability of auditor's proof by replacing manual audit procedures. Process development as a new method of data analysis provides auditors with tools that fully meet modern technological solutions and challenges. Study [10], which emphasizes the importance of technological capabilities of the audit firms in the implementation of advanced data analytics, is a logical continuation of previous findings. Besides, it is noted that the technological capabilities of auditors can be used to support ideas of the possible use of advanced data analytics as well as disseminate solutions 
in practice. A more comprehensive measurement of the effectiveness of internal audit by constructing a system of indices and conducting empirical analysis is discussed in [11]. The authors approached the audit effectiveness a little differently [12]. For example, the paper examines how the reliability of digital records made in an enterprise resource planning system (known as the state system of accounting and budgeting) supports the audit process in the public sector. Disadvantages of this study consist in the fact that its results are limited to thematic orientation and cannot be adapted to other organizations.

Numerous studies are devoted directly to the study of digital technologies of internal audit. Artificial intelligence and blockchain technologies are found among the most popular technologies. Study [13] emphasizes that due to the use of artificial intelligence in the audit of financial reports, leaves profound consequences for the audit purposes and the ways to achieve them. In turn, the authors of [14] investigate the factors that motivate auditors to use blockchain technology. The results show that the expected high productivity and social impact are indicators of the auditors' intentions to use the blockchain. A similar position can be traced in a study [15] that examines features of blockchain technology from the point of view of the persons responsible for external financial reporting and their auditors. Awareness of the problems of the audit community which are considered in this paper can help guide future solutions in the development of blockchain technology and its targeted implementation in accordance with the needs of audit users.

An important role in the state internal audit system belongs to ensuring cybersecurity, so it is advisable to consider some scientific solutions in this area. Study [16] is aimed at the analysis of approaches to cybersecurity to identify key issues and vulnerabilities in terms of internal audit and risk management. This article emphasizes that internal audit should be an integral part of the cybersecurity process. A similar approach is found in [17] which examines factors related to the scale of security/cybersecurity audits and the internal audit function. Based on the study results, the authors conclude that the degree of security/cybersecurity audit is significantly and in direct proportion related to the competence of the internal audit function in relation to risk management and control. Study [18] is considered a generalizing study on cybersecurity. The article examines cybersecurity and information exchange, investment in cybersecurity, internal audit and the control related to cybersecurity, disclosure of cybersecurity activities and threats, and security breaches.

The approach to the development of internal audit proposed by the authors of [19] is radically different from that in previous studies. The paper examines the relationship between characteristics of digital technologies (implementation, confidence, competence, and training) and auditing practices. In addition, the article explains the importance of the audit practice by assessing this relationship.

When summarizing the above studies on digitization of internal audit [3-19], it seems appropriate to identify certain limitations of the studied approaches to the development of a state internal audit in conditions of use of digital technologies:

1. A significant number of studies are devoted to the development of internal audit. However, only a few of them consider the system of state internal audit and legal support of its functioning.
2. Most researchers focus on specific digital internal audit technologies. At the same time, few of them study digital technologies of the state internal audit system in general. At the same time, few of them study digital technologies for the development of the state internal audit system in general.

\section{The aim and objectives of the study}

This study's objective implied the elaboration of recommendations concerning the development of a state internal audit system in conditions of the use of digital technologies. This will create a basis for improving the state's internal audit process by increasing its transparency as well as preventing abuse by regulatory authorities and controlled entities.

To achieve this goal, it was necessary to solve the following tasks:

- study the international experience of introduction of digital technologies in the system of state internal audit that provide improvement of its quality and efficiency;

- analyze digital technologies and establish their compliance with subsystems of state internal audit;

- examine constituent elements of the state internal audit system in a context of digital technologies and establish relationships between them;

- develop a mechanism of development of a system of state internal audit in conditions of application of digital technologies by a schematic display of the sequence of realization of its improvement lines.

\section{The study materials and methods}

Fundamentals of public administration and financial law, concepts of e-government, and the project of digital transformation of financial control have formed the theoretical and methodological basis of the study. Besides, methodological aspects of scientific concepts in the field of internal audit and studies of scholars involved in solving this problem were used.

A system of general, specific, and special methods was used in the study. A structurally logical method was used in the process of constructing the stages of internal audit digitization. International experience in the digitization of state internal audit was examined using the method of comparative analysis. The method of theoretical generalization was used to generalize the results of the study and write conclusions. The expediency of the introduction of digital technologies in the development of the system of state internal audit was substantiated by means of the abstract-logical method. The graphical method was used to construct drawings and diagrams. The method of algorithmization was used to determine components of the development of the internal state audit system in terms of digitization and build a mechanism for the development of an internal state audit system in terms of digital technology. Types of digital technologies in areas of state internal audit were generalized using systematic analysis.

Statistical data of the Ministry of Digital Transformation, the State Audit Office of Ukraine, data from international rankings, reports on digitization of internal audit were used as the study database. Monographs and periodicals on the study topic, materials of scientific and practical conferences, and the author's studies were also used. 


\section{The results obtained in studies on the impact of digital technologies on the development of the state internal audit system}

\begin{abstract}
5. 1. Study of international experience in the digitization of the state internal audit

Global trends related to the latest technological advances in the field of digitization have dramatically changed approaches to the state internal audit procedure in most countries. A gradual transition from one stage of digital technology development to another has led to the expansion of their type diversity in the field of internal audit (Fig. 1).
\end{abstract}

STAGES OF AUDIT DIGITAZATION

\begin{tabular}{|l|r|}
\hline ANALYTICAL & $\begin{array}{r}\text { Technologies of integrated structured } \\
\text { data } \\
\text { visualizing the structured data }\end{array}$ \\
\hline INTELLIGENT & $\begin{array}{r}\text { Robotized technologies of structured } \\
\text { data processing }\end{array}$ \\
\hline Technologies of generation and \\
processing of unstructured data, \\
technologies of distance learning, \\
technologies of e-audit, artificial
\end{tabular}

Fig. 1. Stages of digitization of internal audit
Besides the BARON development, Korea's supreme institution of audit has made significant efforts to promote the use of IT-based auditing including the establishment of dedicated data analysis and information management (DDAIM). This subdivision, together with the Audit and Inspection Research Institute (AIRI), supports the audit units in the retrieval and analysis of digital data and evaluates the BARON operation to improve this system [23].

It is also appropriate to consider the European experience of digital reformation of financial audit using Finland's example. The Finnish state audit institution conducts financial and compliance audits and audits of fiscal policy efficiency. For example, the Supreme Audit Authority of Finland has carried out large-scale reforms in the field of financial audit in 2020. Besides, possibilities of data analysis, centralized quality, and efficiency of implementation were taken into account to provide better services to a larger number of customers. In line with the changes in central government financial management, the reform was aimed at an increase in the use of new digital technologies. Accordingly, the Finnish central government has introduced common information systems for key processes such as accounting, debt collection, personnel administration, automated P2P procurement, and travel. Tasks such as management of access rights are also performed centrally and in a unified manner. Thus, from an audit point of view, all data analysis capabilities are available to cen-

Note: compiled according to [20,21]

Transformational changes in the development of e-government models on a global scale are concurrently taking place. In turn, digitization of state administration systems is taking place, in particular, efforts of most countries in the world to introduce digital technologies in the field of state internal audit are intensifying. Accordingly, it seems appropriate to study successful world experience in the digitization of these processes.

Korea is one of the world leaders in providing state online services and e-government development [22]. Its government is actively using digital technologies such as artificial intelligence, data analytics, $5 \mathrm{G}$ providing high-quality state services. At the same time, a basis is being formed for the introduction of digital technologies in the state audit system. For example, in early 2018, the supreme audit authority of Korea, the Audit Board, has established a BARON system (the best audit and inspection system for a rule-based surveillance network). This system has become the main tool for the acquisition, sorting, and analysis of digital data. It collects data according to specific needs of auditors on a regular (monthly or quarterly) basis and processes and stores data for 653 different audit spheres. Although the BARON has made available various types of data from certain government agencies, auditors initially did not have access to all necessary data. To address this issue, the supreme audit institution has linked the BARON to data stored in the government's metadata management system which included 2,921 information systems and 451,200 databases. This improvement has allowed auditors to search in its lists for digital data on organizations and realize inquiries from persons being audited to provide with any data that could not be retrieved from the system. tral government finance auditors. Data analysis in financial audit can provide many benefits. The methodology based on financial audit standards works well when audits are contion using several control means simultaneously. Available datasets can be used to check how effectively the control means are working. The method of end-to-end testing is useful if high-quality data are available. An analytical substantive audit can be a fairly simple way to forecast the financial resources of the central government. Data analysis is also reducing the time required to identify the risk of violations. However, data analysis can only be used effectively if reliable financial audit data are available. This can often be difficult because the creation of interfaces requires an understanding of (1) audit objectives and working methods, (2) how data are used, and (3) the structure of information systems [24].

Thus, the application of digital technologies when developing the audit processes accelerates and facilitates the identification of potential situations of error occurrence at an early stage. Active use of the technologies of artificial intelligence may be one of the possible and most probable scenarios of the development of a state internal audit system in the nearest future. the state internal audit gained in different countries, it is worth noting that there has been an active introduction of digital technologies in all spheres of state administration over the past five years. During this time, various state registers have been formed which is a prerequisite for improving the state internal audit. The introduction of an electronic audit (e-audit) system having effectiveness ducted using data analysis which enables audit and verifica-

When comparing the experience in the digitization of 
confirmed in various countries around the world is the most important step in this direction. It should be noted that transition to a higher level of the state's auditing activities is realized in close cooperation with European Union. As regards the e-audit, it is planned to introduce (starting from 2023) a fast, accurate, objective, and effective monitoring of taxpayers: only large ones at the first stage and then all the others. As a result of such monitoring, the state will be able to identify the riskiest business entities and suspicious transactions.

\section{2. Analysis of digital technologies} used in the system of state internal audit

Digital transformation of the state internal audit accelerates the process of audit implementation, improves transparency, and enables timely identification of violations on the one hand and the use of digital technologies is associated with certain problems on the other hand. For example, deviations from the algorithm of using a particular technology can lead to inaccurate data. Besides, the confidentiality of data during the audit is of no less importance.

The first problem can be solved by improving the level of competence of IT professionals in the application of the most common digital technologies in auditing. Fig. 2 provides information on the level of competence of Ukrainian IT professionals in the use of the most promising digital audit technologies: artificial intelligence (AI), internet of things (IoT), and big data (Big data) as of 2020 [25].

Big data $(\mathrm{BD})$

\begin{tabular}{|l|l|l|}
\hline $4 \%$ & $96 \%$ \\
\hline & & \\
\hline $1 \%$ & $99 \%$ & \\
\hline
\end{tabular}

Internet of things (IoT)

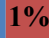

\begin{tabular}{|l|r|r|}
\hline & \\
\hline $14 \%$ & $86 \%$ \\
\hline
\end{tabular}

Artificial intelligence (AI)

$\begin{array}{lrrr}0 \% \quad 20 \% & 40 \% \quad 60 \% & 80 \% \\ & \text { migh level } & \text { — Low level }\end{array}$

Fig. 2. Competences of Ukrainian IT specialists in the use of most promising digital technologies in the field of audit in 2020

Analysis of Fig. 2 shows that out of almost 200,000 specialists in the Ukrainian IT sector, only $4 \%$ have a high level of competence in the field of big data and $1 \%$ in the internet of things. Despite this, the Ukrainian education system graduates almost 30,000 IT professionals yearly. Besides, non-formal IT education and training courses where more than 40,000 Ukrainians improve their skills are gaining popularity [25]. This gives grounds to claim that the level of development of basic digital technologies in the field of audit may increase significantly in the coming years.

The problem of data confidentiality in the audit process can be solved by increasing the level of cybersecurity (cyber power) of the state. In 2020, Ukraine ranked $26^{\text {th }}$ in the ranking of the National Index of Cybersecurity Forces. It should be noted that it is the 10th place among European countries and the 3rd place among the countries of the post-Soviet space [26]. Ukraine ranked 54th in the Global Cyber Security Index in 2019 rising for four positions since 2017 [27]. According to many experts, the development of cybersecurity in Ukraine is slow and needs to be accelerated.

In addition, in order to ensure the quality of state internal audit, it is advisable to identify types of digital technologies used in different areas (Fig. 3).

\section{Types of digital technologies of state} internal audit

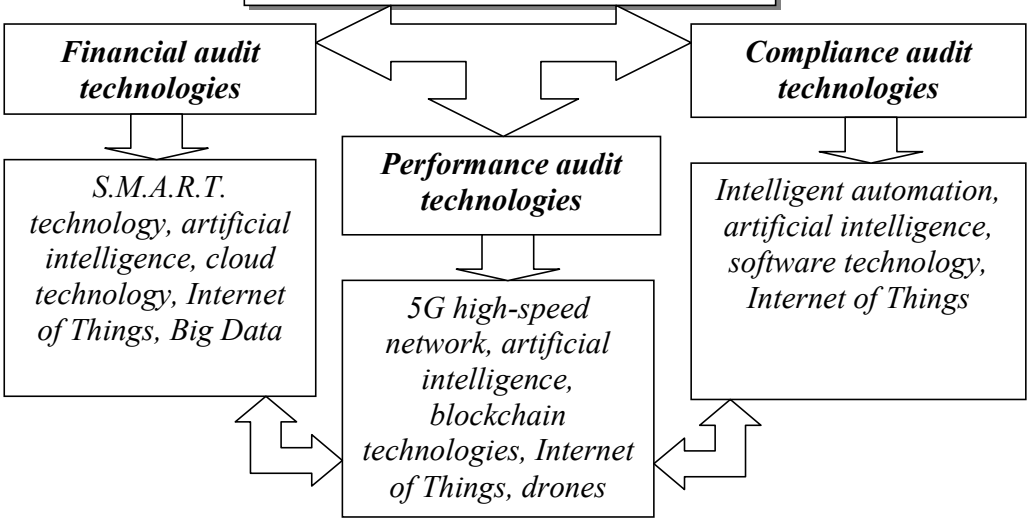

Fig. 3. Types of digital technologies in the system of state internal audit Note: compiled according to [28-34]

It is worth noting that the maximum effect from the use of digital technologies in the field of audit will take place in the case of their synergistic combination. This will help solve a number of problems. First of all, a comprehensive analysis will be provided in the audit process through the integrated application of digital technologies. Besides, the degree of subjectivity in auditing will be reduced significantly through the active use of artificial intelligence technologies. The process of audit will also be accelerated due to the automation and algorithmization of data. The synergistic combination of digital technologies will make it possible to fully realize new opportunities for digitization in the audit field which will significantly improve their quality and create a basis for the development of the state internal audit system.

5. 3. The study of components of the system of state internal audit in conditions of digitization

At the present stage, the quality of the state internal audit system is directly dependent on the level of digitization in planning, organization, and implementation of audit procedures. The development of the state internal audit system in terms of digitization is presented in Fig. 4. Within the framework of the development of the state internal audit system in conditions of digitization, there is a coordinated interaction of the State Audit Office of Ukraine and relevant services (entities) with activities of state bodies and internal control measures (objects). Results of this interaction are 
influenced by threats from internal and external factors, as well as risks.

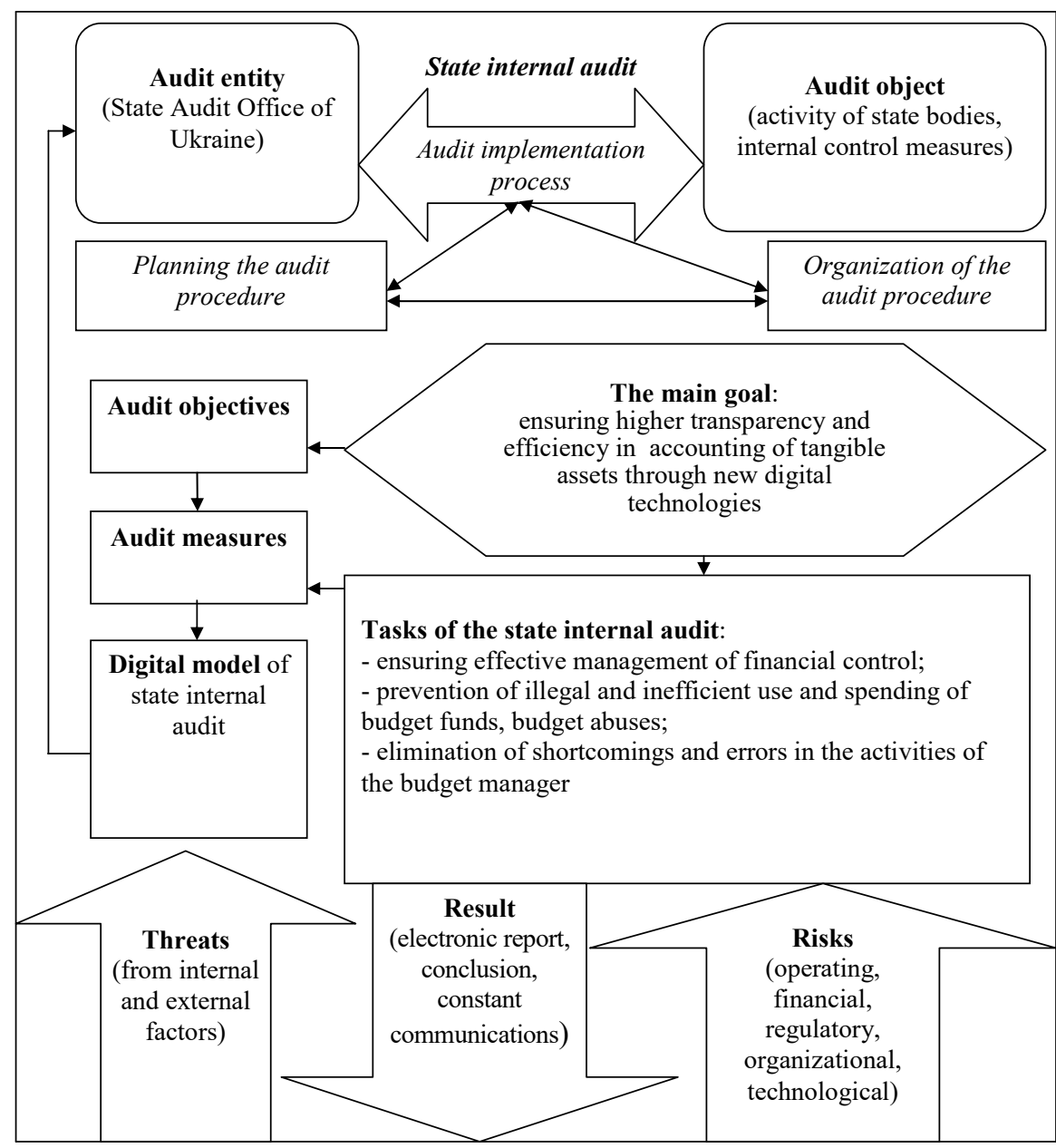

Fig. 4. Development of the state internal audit system in conditions of digitization Note: compiled according to [20,28,35-37]

In order to implement an internal audit, the State Audit Office plans the audit procedure. Firstly, activities of the auditee itself are planned, and secondly, an appropriate audit is planned. Audit planning creates preconditions for the organization and implementation of audit procedures by assessing priorities, setting goals, clearly setting objectives, and identifying potential opportunities. It is also important to take into account socio-economic and politico-legal conditions on which the system of state internal audit is based.

In many cases, inconsistencies in components of the state internal audit system cause ineffective control over activities of state bodies and permit abuses by the latter.

In order to construct an effective system of state internal audit in the context of digitization, it is important, first of all, to adhere to the goals and objectives of the audit and ensure a high organizational and technical level of audit procedures.

\section{4. Elaboration of a mechanism of development of} the state internal audit system in conditions of use of digital technologies

To work out directions in the development of the state internal audit system in conditions of use of digital technologies, it was proposed to use a special mechanism shown schematically in Fig. 5.
According to the proposed mechanism, development of the state internal audit system in conditions of use of digital technologies, all variety of measures should be presented as follows (1):

$$
A=\left\{A_{1}, \ldots, A_{n}, \ldots, A_{N}\right\}
$$

where $\mathrm{A}^{B} \subset \mathrm{A}$ is for the main measures to be taken for the development of the state internal audit system;

$\mathrm{A}^{D} \subset A$ is for the measures to be taken for the development of the state internal audit system through the use of digital technologies.

In other words, the development of the state internal audit system in conditions of use of digital technologies can be represented in a form of a graph in which vertices will be measures or lines of development.

In turn, each measure or line of development contains the following set of indicators (2):

$$
A_{N}\left\{A_{i N}, R_{N}, P_{N}, L_{N}\right\}
$$

where $A_{i N}$ is for the $i$-th measure of the development of the state internal audit system;

$R_{N}$ is for resource costs subject to the implementation of the $N$-th measure of the development of the state internal audit system;

$P_{N}$ is for responsible persons or executors of the $\mathrm{N}$-th measure of the development of the state internal audit system;

$L_{N}$ is for losses in case of inefficiency of the $N$-th measure of the development of the state internal audit system.

Indicators (tops of the graph) of the development of the state internal audit system in conditions of digitization can be expressed in the following subgraphs:

$$
\begin{aligned}
& A_{i N}\left\{A_{i N 1}, A_{i N 2}, \ldots, A_{i N k}\right\}, \\
& R_{N}\left\{R_{N 1}, R_{N 2}, \ldots, R_{N k}\right\}, \\
& P_{N}\left\{P_{N 1}, P_{N 2}, \ldots, P_{N k}\right\}, \\
& L_{N}\left\{L_{N 1}, L_{N 2}, \ldots, L_{N k}\right\},
\end{aligned}
$$

where $A_{i N k}$ is for the $k$-th digital measure of the development of the state internal audit system;

$R_{N k}$ is for additional resource costs in transition from the $N$-th to the $k$-th digital measure of the development of the state internal audit system;

$P_{N k}$ is for responsible persons or executors of the $k$-th digital measure of the development of the state internal audit system;

$L_{N k}$ is for losses in a case of inefficiency of the $k$-th digital measure of the development of the state internal audit system. 


\begin{tabular}{|c|c|c|c|}
\hline \multicolumn{2}{|c|}{$\begin{array}{l}\text { Assessment of the digital potential of } \\
\text { the state internal audit }\end{array}$} & \multicolumn{2}{|c|}{$\begin{array}{l}\text { Formulation of goals of the state } \\
\text { internal audit }\end{array}$} \\
\hline $\begin{array}{l}\text { Elaboration of } \\
\text { measures for } \\
\text { introduction of } \\
\text { digital } \\
\text { technologies in } \\
\text { auditing }\end{array}$ & $\begin{array}{c}\text { Comparison of } \\
\text { digital } \\
\text { potential with } \\
\text { elaborated } \\
\text { measures }\end{array}$ & $\begin{array}{l}\text { Defining the } \\
\text { main purpose } \\
\text { of the audit }\end{array}$ & $\begin{array}{c}\text { Decompositior } \\
\text { of audit } \\
\text { objectives, } \\
\text { planning and } \\
\text { organization o } \\
\text { audit activities }\end{array}$ \\
\hline \multicolumn{4}{|c|}{$\begin{array}{l}\text { Working out lines of development of the system of state internal audit in } \\
\text { conditions of use of digital technologies }\end{array}$} \\
\hline \multicolumn{2}{|c|}{$\begin{array}{c}\text { Elaboration of basic measures for } \\
\text { development of the state internal } \\
\text { audit system }\end{array}$} & \multicolumn{2}{|c|}{$\begin{array}{l}\text { Consolidation of measures for } \\
\text { development of the state internal } \\
\text { audit system by executors }\end{array}$} \\
\hline \multicolumn{2}{|c|}{ 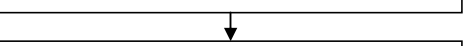 } & \multicolumn{2}{|c|}{4} \\
\hline \multicolumn{2}{|c|}{$\begin{array}{c}\text { Determining the amount of } \\
\text { necessary resources for } \\
\text { implementation of the proposed } \\
\text { main measures }\end{array}$} & \multicolumn{2}{|c|}{$\begin{array}{c}\text { Elaboration of measures for } \\
\text { organizational development of the } \\
\text { state internal audit system through the } \\
\text { use of digital technologies }\end{array}$} \\
\hline \multicolumn{2}{|c|}{$\downarrow$} & \multicolumn{2}{|c|}{$\downarrow$} \\
\hline \multicolumn{2}{|c|}{$\begin{array}{l}\text { Evaluation of effectiveness of } \\
\text { implementation of main measures } \\
\text { for development of the state } \\
\text { internal audit system }\end{array}$} & \multicolumn{2}{|c|}{$\begin{array}{l}\text { Determining the amount of necessary } \\
\text { resources for implementation of } \\
\text { proposed measures through } \\
\text { digitization }\end{array}$} \\
\hline \multicolumn{4}{|c|}{$\begin{array}{l}\text { Estimation of efficiency of development of the system of state } \\
\text { internal audit in conditions of use of digital technologies }\end{array}$} \\
\hline
\end{tabular}

Fig. 5. The mechanism of development of the system of state internal audit in conditions of use of digital technologies

Note: compiled according to [28,33,34,38,39]

To assess the effectiveness of the development of the state internal audit system in conditions of use of digital technologies, the indicators reflecting overall results of public financial control $[39,40]$ can be used. In particular, such indicators include the number of resources covered by the control, the number of violations that led to the loss of resources, additional results (effect) of the proposals based on the results of audits, etc. Generalization of existing approaches has allowed us to form an algorithm of calculating the influence of the economic effect of digital technologies on the development of the state internal audit system consisting of three main stages:

1. Stage 1. The amount of budget expenditures for digitization of the state internal audit $\left(B E_{D I A}\right)$ is determined.

2. Stage 2. The Sum of money that has been returned to the budget and/or precautionary measures taken against future budget expenditures based on the results of a better audit $(B R)$ are determined.

3. Stage 3. The coefficient of efficiency of influence of digital technologies on the development of the system of the state internal audit $\left(E_{D I A}\right)$ is defined:

$$
E_{D I A}=B R / B E_{D I A}
$$

In this case, optimal conditions are those under which $B R=B E_{D I A}$, i.e. when $E_{D I A} \rightarrow 1$.
Besides, it is possible to determine the economic and/or social effect of the impact of digital technologies on the development of the state internal audit by comparing the indicators before and after implementation of the proposed measures.

\section{Discussion of results obtained in the study of the impact of digital technologies on the development of the state internal audit system}

Analysis of international experience in the development of the state internal audit system in conditions of using digital technologies shows that most countries around the world are at the stage of intellectual audit digitization. Unlike the previous stages, the current stage is characterized by the use of more advanced digital technologies: generating and processing unstructured data, remote learning, e-audit, artificial intelligence (Fig. 1).

Further study of worldwide digitization lines has revealed that Korea is one of the leaders in providing public online services and e-government development. In this regard, a detailed description of the functioning of the state audit system in terms of digitization was presented on the basis of $[23,34]$. Besides Asian experience in internal audit digitization, European experience was also studied, in particular, digital reformation of financial audit on the example of Finland. In contrast to Korea, Finland has a well-established methodology of conducting financial audits using data analysis which makes it possible to carry out auditing and verification by several control means simultaneously [24].

In contrast to [13-18] which provide description and substantiation of the importance of a particular type of digital technology in performing the internal audit, digital technologies have been generalized by the lines of state internal audit (Fig. 3). It was pointed out that the maximum effect from the use of digital technologies in the field of audit will only take place in the case of their synergistic combination.

The study of components of the state internal audit system in conditions of digitization has proved that the quality of this system is directly dependent on the digitization of planning, organization, and implementation of audit procedures. Accordingly, a scheme of development of the state internal audit system in conditions of digitization was developed (Fig. 4).

Analysis of the relationship between the development of the state internal audit system and the use of digital technologies has allowed us to propose an algorithm of this process mechanism (Fig. 5). The results of the study on the elaboration of recommendations for the development of the state internal audit system in conditions of use of digital technologies provide a basis for improving the quality of 
audit procedures. In turn, this will ensure targeted use of budget funds and prevent abuse by officials.

The practical significance of the study is confirmed by the proposed classification of digital technologies by areas of the state internal audit. Also, the algorithm of development of the state internal audit system in conditions of digitization is of practical interest.

When analyzing the content of proposed provisions, it should be noted that some of the study results are substantiated insufficiently. This indicates a relative limitation of scientific and methodological elaboration.

Further development of studies initiated in this publication is advisable to be carried out by theoretical and methodological deepening of the proposed solutions and recommendations for the development of the state internal audit in conditions of digitization. Particular attention should be paid to improving the mechanism of development of the state internal audit system through the introduction of digital technologies as well as assessing the effectiveness of proposed measures.

\section{Conclusions}

1. It was established that the development of the state internal audit systems in most countries mainly depends on the use of digital technologies. The sequence of stages of digitization of internal audit was singled out and digital technologies corresponding to each of them were presented. It has been proven that the development of e-government models on a global scale intensifies efforts of most countries in the introduction of digital technologies in the field of state internal audit. Successful Asian and European experience in the digital reform of the state internal audit was singled out and analyzed. It was proved that one of the possible and most probable scenarios of the development of the state internal audit system in the near future may consist in the active use of artificial intelligence technologies.

2. Positive and negative aspects of the process of digitization of the state internal audit were characterized. The competence of Ukrainian IT specialists in the use of the most promising digital technologies in the field of auditing was analyzed and its low level was shown. Ukraine's rating in cybersecurity was established which gives grounds to claim that cybersecurity is slowly developing and needs to be fastened. Types of digital technologies were systematized in three state internal audit areas: financial, effectiveness, and compliance audits. It was established that the maximum effect of the use of digital technologies in the field of audit will take place in the case of their synergistic combination. This will make it possible to fully realize new opportunities for digitization and create a basis for the development of the state's internal audit system.

3. It was established that the quality of the state internal audit system is directly dependent on the level of digitization in planning, organization, and implementation of the audit procedures. Interaction of the State Audit Office of Ukraine with relevant services (entities) with activities of state bodies and internal control measures (objects) has been agreed upon. This has created a basis for constructing an algorithm of development of the state internal audit system in conditions of digitization. It was proved that a mismatch of the constituent elements of the state internal audit system causes ineffective control over activities of state bodies and leads to abuses by the latter.

4. The results of the study of components of the state internal audit system have created a basis for a schematic representation of the mechanism of its development in conditions of the use of digital technologies. It was substantiated that the development of the state internal audit system in conditions of using digital technologies can be represented as a peculiar graph with its vertices being measures or development lines. It was found that to assess the effectiveness of the state internal audit system in conditions of use of digital technologies, the indicators reflecting overall results of state financial control can be used. The economic and/or social effect of the impact of digital technologies on the development of public internal audit can be determined by comparing the indicators before and after implementation of the proposed measures.

\section{References}

1. Tsyfrovizatsiya - tse postupove peretvorennia usikh derzhavnykh posluh na zruchni onlain-servisy (2021). Available at: https:// www.rv.gov.ua/news/cifrovizaciya-ce-postupove-peretvorennya-usih-derzhavnih-poslug-na-zruchni-onlajn-servisi

2. Tsyfrova transformatsiya derzhavnoho finansovoho kontroliu (e-Audytor) (2021). Derzhavna audytorska sluzhba Ukrainy. Available at: https://dasu.gov.ua/ua/news/3602

3. Petrakaki, D. (2018). Re-locating accountability through technology: From bureaucratic to electronic ways of governing public sector work. International Journal of Public Sector Management, 31 (1), 31-45. doi: https://doi.org/10.1108/ ijpsm-02-2017-0043

4. Engelbrecht, L., Yasseen, Y., Omarjee, I. (2018). The role of the internal audit function in integrated reporting: a developing economy perspective. Meditari Accountancy Research, 26 (4), 657-674. doi: https://doi.org/10.1108/medar-10-2017-0226

5. Awuah, B., Onumah, J. M., Duho, K. C. T. (2021). Determinants of adoption of computer-assisted audit tools and techniques among internal audit units in Ghana. The Electronic Journal of Information Systems in Developing Countries. doi: https://doi. org/10.1002/isd2.12203

6. Betti, N., Sarens, G. (2020). Understanding the internal audit function in a digitalised business environment. Journal of Accounting \& Organizational Change, 17 (2), 197-216. doi: https://doi.org/10.1108/jaoc-11-2019-0114

7. How the internal audit function is evolving: The impact of digitalization (2021). Strategic Direction, 37 (7), 24-26. doi: https:// doi.org/10.1108/sd-06-2021-0055

8. Islam, S., Stafford, T. (2021). Factors associated with the adoption of data analytics by internal audit function. Managerial Auditing Journal, 37 (2), 193-223. doi: https://doi.org/10.1108/maj-04-2021-3090 
9. Werner, M., Wiese, M., Maas, A. (2021). Embedding process mining into financial statement audits. International Journal of Accounting Information Systems, 41, 100514. doi: https://doi.org/10.1016/j.accinf.2021.100514

10. Krieger, F., Drews, P., Velte, P. (2021). Explaining the (non-) adoption of advanced data analytics in auditing: A process theory. International Journal of Accounting Information Systems, 41, 100511. doi: https://doi.org/10.1016/j.accinf.2021.100511

11. Gaosong, Q., Leping, Y. (2021). Measurement of Internal Audit Effectiveness: Construction of Index System and Empirical Analysis. Microprocessors and Microsystems, 104046. doi: https://doi.org/10.1016/ j.micpro.2021.104046

12. Mosweu, O., Ngoepe, M. (2021). Trustworthiness of digital records in government accounting system to support the audit process in Botswana. Records Management Journal, 31 (1), 89-108. doi: https://doi.org/10.1108/rmj-11-2019-0069

13. Gao, Y., Han, L. (2021). Implications of Artificial Intelligence on the Objectives of Auditing Financial Statements and Ways to Achieve Them. Microprocessors and Microsystems, 104036. doi: https://doi.org/10.1016/ j.micpro.2021.104036

14. Ferri, L., Spanò, R., Ginesti, G., Theodosopoulos, G. (2020). Ascertaining auditors' intentions to use blockchain technology: evidence from the Big 4 accountancy firms in Italy. Meditari Accountancy Research, 29 (5), 1063-1087. doi: https:// doi.org/10.1108/medar-03-2020-0829

15. Sargent, C. S. (2021). Replacing Financial Audits with Blockchain: The Verification Issue. Journal of Computer Information Systems. doi: https://doi.org/10.1080/08874417.2021.1992805

16. Bozkus Kahyaoglu, S., Caliyurt, K. (2018). Cyber security assurance process from the internal audit perspective. Managerial Auditing Journal, 33 (4), 360-376. doi: https://doi.org/10.1108/maj-02-2018-1804

17. Islam, M. S., Farah, N., Stafford, T. F. (2018). Factors associated with security/cybersecurity audit by internal audit function: An international study. Managerial Auditing Journal, 33 (4), 377-409. doi: https://doi.org/10.1108/maj-07-2017-1595

18. Haapamäki, E., Sihvonen, J. (2019). Cybersecurity in accounting research, Managerial Auditing Journal, 34 (7), 808-834. doi: https://doi.org/10.1108/maj-09-2018-2004

19. Thottoli, M. M., Thomas, K. V. (2020). Characteristics of information communication technology and audit practices: evidence from India. VINE Journal of Information and Knowledge Management Systems. doi: https://doi.org/10.1108/ vjikms-04-2020-0068

20. Auditing the risks of disruptive technologies: Internal Audit in the age of digitalization (2018). Deloitte Development LLC. Available at: https://www2.deloitte.com/content/dam/Deloitte/us/Documents/finance/us-rfa-auditing-the-risks-ofdisruptive-technologies.pdf

21. Elektronnyi audyt: svitovi nadbannia ta vitchyzniani realiyi: zbirnyk materialiv naukovo-praktychnoho kruhloho stolu (2018). Irpin: NDI fiskalnoi polityky, 64.

22. E-Government: Survey 2020 (2020). United Nations, 364. Available at: https://publicadministration.un.org/egovkb/Portals/ egovkb/Documents/un/2020-Survey/2020\%20UN\%20E-Government\%20Survey\%20(Full\%20Report).pdf

23. Sooyeon, L., Taeick, K., Choongjae, L. (2021). IT-Based Audits: A Powerful Tool In A Changing Audit Environment. INTOSAI Journal. Available at: http://intosaijournal.org/it-based-audits-a-powerful-tool/

24. VOA Finlyandiya ispol'zuet analiz dannyh dlya reformirovaniya finansovogo audita (2021). Mezhdunarodniy zhurnal gosudarstvennogo audita, 48 (1), 13. Available at: https://www.intosai.org/fileadmin/downloads/about_us/IJGA_Issues/2021/ RU_2021_v48n1.pdf

25. 2 liutoho - publichne obhovorennia proektu NES-2030 «Tsyfrova ekonomika ta informatsiino-kompiuterni tekhnolohiyi (IKT)» (2021). Available at: https://www.kmu.gov.ua/events/2-lyutogo-publichne-obgovorennya-proektu-nes-2030-cifrova-ekonomikata-informacijno-kompyuterni-tehnologiyi-ikt

26. Novyi hlobalnyi indeks kiberbezpeky - Natsionalnyi indeks kiberpotuzhnosti. Available at: https://www.icu-ng.org/icu-ng/ novyny/novyj-globalnyj-indeks-kiberbezpeky-naczionalnyj-indeks-kiberpotuzhnosti/\#_ftnref4

27. Kiberbezpeka $v$ informatsiynomu suspilstvi: Informatsiyno-analitychnyi daidzhest (2019). Kyiv, 121. Available at: http://ippi.org. ua/sites/default/files/2019-10.pdf

28. Azy kontroliu i niuansy audytu: Praktychnyi posibnyk dlia predstavnykiv mistsevykh orhaniv vlady (2019). Kyiv: LOGICA, 46. Available at: https://oda.carpathia.gov.ua/sites/default/files/imce/190604_kontrol_audit.pdf

29. Ivanova, L. I. (2020). Tsyfrova transformatsiya audytu. Oblik, analiz, audyt ta opodatkuvannia: suchasna paradyhma v umovakh staloho rozvytku: Materialy VI Mizhnarodnoi naukovo-praktychnoi konferentsiyi, prysviachenoi 20-y richnytsi stvorennia kafedry audytu. Kyiv: KNEU, 412-414. Available at: https://ir.kneu.edu.ua/bitstream/handle/2010/35081/Oaao_20_12_159. pdf?sequence $=1 \&$ isAllowed $=\mathrm{y}$

30. Yakimova, V. (2020). Opportunities and prospects for using digital technologies in auditing. St Petersburg University Journal of Economic Studies, 36 (2), 287-318. doi: https://doi.org/10.21638/spbu05.2020.206

31. Povyshaya rol' vnutrennego audita: gotovnost' k tsifrovoy transformatsii. Available at: https://www.pwc.ru/ru/publications/ internal-audit-transformation-study.html

32. Korol, S., Klochko, A. (2020). Digital technologies in accounting and auditing. State and regions. Series: Economics and Business, 1 (112), 170-176. doi: https://doi.org/10.32840/1814-1161/2020-1-29 
33. Dunayev, I., Kud, A., Latynin, M., Kosenko, A., Kosenko, V., Kobzev, I. (2021). Improving methods for evaluating the results of digitizing public corporations. Eastern-European Journal of Enterprise Technologies, 6 (13 (114)), 17-28. doi: https://doi.org/10.15587/ 1729-4061.2021.248122

34. Kud, A. (2021). Decentralized information platforms in public governance: reconstruction of the modern democracy or comfort blinding? International Journal of Public Administration. doi: https://doi.org/10.1080/01900692.2021.1993905

35. Slobodianyk, Yu. B. (2014). Formuvannia systemy derzhavnoho audytu v Ukraini. Sumy: FOP Natalukha A. S., 321. Available at: http://dspace.oneu.edu.ua/jspui/handle/123456789/2913

36. Dukhnevych, O. V. (2020). The general fundamentals of functioning of the public internal financial control in Ukraine. Scientific Notes of Taurida V.I. Vernadsky University. Series: Public Administration, 31 (70 (5)), 17-22. doi: https://doi.org/10.32838/TNU2663-6468/2020.5/04

37. Shevchenko, N. V. (2016). Development of state financial control: current trends and priority areas. Efektyvna ekonomika, 12. Available at: http://www.economy.nayka.com.ua/?op=1\&z=5321

38. Pushkarova, O. (2019). The mechanism of the building an effective internal control system by the administrators of budget funds. Black Sea Economic Studies, 47-2, 151-157. doi: https://doi.org/10.32843/bses.47-62

39. Analitychno-statystychnyi zbirnyk za rezultatamy diyalnosti Derzhavnoi audytorskoi sluzhby Ukrainy, yii mizhrehionalnykh terytorialnykh orhaniv: sichen-cherven 2021 roku (2021). Kyiv, 180. Available at: https://statewatch.org.ua/wp-content/ uploads/2021/09/Analitychno_statystychnyy_zvit_I_pivrichchia_2021.pdf

40. Dmytryk, O. O., Kostenko, Y. O., Monaienko, A. O., Riadinska, V. O., Soldatenko, O. V. (2020). State Legal Forms of Interaction with Debt Obligations and State Losses. Journal of Advanced Research in Law and Economics, 11 (2), 342. doi: https://doi.org/10.14505/ jarle.v11.2(48).07 